\begin{tabular}{|c|c|c|}
\hline()$_{\text {SiiRT }}^{\prime}$ & $\begin{array}{c}\text { Türkiye Tarımsal Araştırmalar Dergisi } \\
\text { dergipark.org.tr/tutad }\end{array}$ & $\begin{array}{l}\text { Turk J Agric Res } \\
\text { 2019, 6(2): 123-135 } \\
\text { ○) TÜTAD } \\
\text { ISSN: 2148-2306 }\end{array}$ \\
\hline $\begin{array}{l}\text { ÜNIVERSiTESi } \\
\text { Bulimimin Jïünda }\end{array}$ & Araştırma Makalesi / Research Article & $\begin{array}{l}\text { e-ISSN: } 2528-858 \mathrm{X} \\
\text { doi: } 10.19159 / \text { tutad.428732 }\end{array}$ \\
\hline
\end{tabular}

\title{
Süt Sığırcılığı İşletmelerinin Memnuniyet ve Sürdürülebilirliğine Etkili Olan Faktörler: Muş İli Örneği
}

\author{
Galip BAKIR $^{1 *}$, Mustafa KİBAR ${ }^{2}$ \\ ${ }^{1}$ Kahramanmaraş Sütçü İmam Üniversitesi, Ziraat Fakültesi, Zootekni Bölümü, Kahramanmaraş, TÜRKIYYE \\ ${ }^{2}$ Siirt Üniversitesi, Ziraat Fakültesi, Zootekni Bölümü, Siirt, TÜRKIYYE
}

\begin{tabular}{ll}
\hline \multicolumn{1}{c}{ Geliş Tarihi/Received: 30.05 .2018} & Kabul Tarihi/Accepted: 26.03 .2019 \\
\hline ORCID ID (Yazar sirasina göre / by author order) & \\
\hline (Dorcid.org/0000 $00020816227 X$ (D)orcid.org/0000 $00021895019 \mathrm{X}$ & \\
\hline "Sorumlu Yazar/Corresponding Author: galipbakir@hotmail.com
\end{tabular}

Öz: Bu çalıșma, Muş ilindeki büyükbaș hayvancılık işletmelerinin memnuniyet ve sürdürülebilirliği ile buna etkili olduğu düşünülen; işletme mevki ve tipi, işletmecilerin yaşı, eğitim durumu, hayvancılık yapılan süre, hayvan mevcudu ve ırkı gibi faktörlerin etkilerini araştırmak amacıyla yapılmıştır. Araştırma materyalini, Muş il merkezi ve 5 ilçesinde 346 işletmede yapılan anket verileri oluşturmaktadır. Elde edilen verilerin çapraz tabloları SPSS paket programında oluşturulmuş ve önemlilik testi için ki-kare analizi yapılmıştır. Analiz sonucu, frekans değerlerine göre, işletmecilerin \% 59.4'ünün hayvancılıktan memnun oldukları ve \% 88.9'unun hayvancıllğı sürdürmek istedikleri belirlenmiş; sürdürme nedeni olarak işletmecilerin \% 43.3'ünün başka işlerinin olmadığı, \% 20.1'inin hayvancılığı karlı bulduğu, \% 18.5'inin elde ettiği gelirin kendilerine yettiği, \% 9.4'ünün hayvancılı̆̆g sevdiği; sürdürmeme nedeni olarak ise hayvancıllğın karlı olmadığı (\% 72.5), zamanın olmaması (\% 21.5) ve hayvancılığı sevmeme (\% 6) gibi faktörler tespit edilmiştir. Hayvancılıktan memnuniyet ve işi sürdürmeye etkili olan işletme mevki ve tipi, işletmecilerin yaş ve eğitim durumu, hayvancıllk yapılan süre, hayvan mevcudu ve ırkı gibi faktörlerin etkileri önemli $(p<0.01)$ bulunmuştur. Sonuç olarak, işletmecilerin hayvancıllktan memnun olduğu ve hayvancılık faaliyetini sürdürmek için karlılık, elde edilen gelirin yeterli görülmesi ve başka işlerinin olmaması gibi faktörlerin ön plana çıktığı belirlenmiştir. İşletmelerin devamlılı̆g 1 için, hayvancılıktan elde edilen gelirin artırılması ve maliyetin düşürülmesi yönünde teşviklerin faydalı olacağı düşünülmektedir.

Anahtar Kelimeler: Büyükbaş işletmesi, memnuniyet, sürdürülebilirlik, Muş

\section{The Factors Affecting the Satisfaction and Sustainability of the Dairy Cattle Farms: The Case of Muş Province}

\begin{abstract}
This study was conducted for the purpose of investigating the satisfaction and sustainability of bovine livestock farms in Muş province along with certain factors known to affect these parameters such as age, educational status, duration of livestock farming, number of animals and race. The research material consisted of the survey data collected from 346 farms in Muş province and 5 districts. Crosstables of data are constituted on SPSS package program and chi square analysis are done for significance testing. Our analysis revealed that $59.4 \%$ of the farmers were satisfied with livestock farming and $88.9 \%$ of them wanted to keep their livestock. When asked about the reason of the desire for keeping their livestock; $43.3 \%$ of the farmers replied that they had no other jobs, $20.1 \%$ said that they found the livestock farming profitable, $18.5 \%$ declared that they were happy with the income and $9.4 \%$ indicated that they enjoyed livestock farming. On the other hand, when the farmers who did not have the desire of keeping their livestock farms were asked about the reason of their choices, the results turned out to be as $72.5 \%$ finding it non-profitable, $21.5 \%$ not having enough time, and $6 \%$ not enjoying animal farming. The effect of the factors such as the type and location of the establishment, the age and educational status of the farmers, the length of the livestock farming, the number of animals and the race were found to be statistically significant $(p<0.01)$ on these decisions. As a result, it is determined that most farmers are satisfied with the livestock and the factors such as profitability, sufficient income and lack of other jobs come to the fore in order to maintain livestock activity. In order to sustain the enterprises, incentives for increasing the income from livestock and reducing the cost are thought to be beneficial.
\end{abstract}

Keywords: Cattle farm, satisfaction, sustainability, Muş 


\section{Giriş}

Türkiye'de, 2010 yılında toplam 11.369 .800 baş sığır mevcut olup; kültür, melez ve yerli irkların payları sirasiyla \% $36.92, \% 41.40$ ve $\% 21.68$ şeklindedir. Türkiye İstatistik Kurumu'nun 2017 yılı verilerine göre ise toplam sığır varlığ1 15.943.586 baş olup, kültür, melez ve yerli irkların oranları sirasiyla \% 48.95, \% 41.00 ve $\% 10.05$ 'tir (Anonim, 2019). Bu verilere ek olarak; yıllar itibariyle Türkiye'de yıllık ortalama süt veriminin arttığı, ancak bu artışın toplam sığır varlığ1 içerisindeki kültür ve melez sığır sayısının artmasından ve yerli ırkların sayısının azalmasından kaynaklandığı, ırkların genetik potansiyellerinin ortaya çıkarılmasını sağlayacak çevre koşullarının sağlanmadığı ve dolayısıyla süt veriminin istenilen seviyelerin gerisinde kaldığı bildirilmektedir (Kibar ve Bakır, 2018). Sürdürülebilir bir süt sığırcılığı için hayvanların genetik kapasitesinden fizyolojik sinırlar içerisinde maksimum yararlanmak gerekmektedir. $\mathrm{Bu}$ nedenle Türkiye'de mevcut durumda, sürdürülebilir bir süt sığırcılığından bahsetmek pek mümkün görünmemektedir.

Sürdürülebilirlik kelime anlamı olarak; çeşitlilik ve üretkenliğin devamlılığı sağlanırken, daimi olabilme yeteneğini korumak olarak tanımlanır. Doğal kaynakların yok olma ihtimalinin fark edilmesiyle ortaya çıkan bir kavramdır. Ayrıca sürdürülebilirlik; doğanın ve gelecek kuşakların gereksinimlerine cevap verme yeteneğini tehlikeye atmadan, günlük ihtiyaçları temin ederek, kalkınmayı sürdürülebilir kılma yeteneğine sahip olma veya ekonomik, çevresel koşulların ve toplumsal gereksinimlerin gelecek kuşakların yaşam koşullarına zarar vermeden karşılanmalarını hedefleyen bir dünya görüşü olarak tanımlanmaktadır. Sürdürülebilir tarım, uzun dönemde doğal kaynakların korunmasının yanı sıra çevreye zarar vermeyen tarımsal teknolojilerin kullanıldığı bir tarımsal yapının oluşturulmasıdır. Türkiye'de, tarım tamamen endüstriyel karakter kazanmamakla birlikte dünyanın gelişmiş ülkelerinde olduğu gibi, bir yandan sentetik üretim girdileri denetimsizce kullanılmakta, diğer yandan da günümüzde olumsuz işleme teknik ve teknolojilerin oluşturdukları sonuçları düşünmeden oldukça yoğun bir tarımsal üretim yapılmaktadır. Günümüzde bu uygulamaların doğal dengenin bozulmasina olan etkileri ve besin zinciri yoluyla insanın yanı sıra tüm canlılara ulaşabilen yaşamsal tehlike yaratma özellikleri de sanayi ya da kentsel kirlilikler kadar dikkat çekmeye başlamıştır (Turhan, 2005; Pezikoğlu, 2012).

Bugün hayvancılığın sürdürülebilirliği açısından; hayvan hastalıkları ile mücadelenin etkin yapılması, özellikle yem gibi üretim maliyetlerinin düşürülmesi ve damızlık temini için ırk 1slahında başarının artması ve ürünlerin değer fiyatta satılmasına uygun pazarların oluşturulması önemli unsurlardır. Ayrıca, işletmecilerin hayvansal üretimdeki deneyim sürelerinin bilinmesi, yetiştiricilerin hayvancılığg sürdürülebilir kıldıklarının göstergesi olarak değerlendirilebileceği anlamına gelmektedir. Yetiştirici düzeyinde 1slah ve çevre faktörlerinin iyileştirilmesine yönelik yapılacak bütün çalışmalarda başarılı olabilmek, doğrudan doğruya yetiştiricilerin katılımlarına bağlıdır. Yetiştiricilerin katılımları ise, yapılacak çalışmaların onların ihtiyaçlarına yönelik olması durumunda sağlanabilir. Yetiştiricilerin hangi noktalarda nelere ihtiyaçlarının olduğunu belirlemenin yegâne yolu ise, sahaya inip yetiştiricilerin problemlerini bire bir tespit etmekten geçmektedir. $\mathrm{Bu}$ amaçla Türkiye'nin birçok yöresinde sığırcılık işletmelerinin yapısal özelliklerini araştırmak üzere yürütülen çalışmalar son yıllarda artış göstermiştir (Tugay ve Bakır, 2009; Şeker ve ark., 2012; Bakan ve Aydın, 2016; Koçyiğit ve ark., 2016).

$\mathrm{Bu}$ araştırma; Muş ilinde bulunan süt sığırcılığı işletmelerinde hayvancılıktan memnuniyet ve hayvancılik işletmelerinin sürdürülebilirliği ile bunlara etkili olduğu düşünülen işletme mevki ve tipi, işletmecilerin yaş1, eğitim durumu, hayvancılık yapılan süre, hayvan mevcudu ve 1 rk1 gibi faktörlerin etkilerini araştırmak amacıyla yapılmıştır.

\section{Materyal ve Yöntem}

Araştırma materyalini, Türkiye'nin Doğu Anadolu Bölgesi'nde yer alan Muş ili Merkez ve ilçeleri (Malazgirt, Bulanık, Hasköy, Korkut ve Varto) ile bağlı köylerde bulunan büyükbaş hayvancılık işletmelerinde yüz yüze yapılan anket verileri oluşturmuştur. Araştırmada, büyükbaş hayvan varlığı bakımından ilçeleri temsil eden köyler, bölgede görev yapan veteriner hekimlerin görüşü alınarak belirlenmiştir. Muş yöresine kayıtlı büyükbaş hayvancılık işletmelerinden 2017 yılında anket yolu ile veriler toplanmıştır. Muş Tarım ve Orman İl Müdürlügü kayıtlarından alınan toplam işletme sayısı dikkate alınarak, 346 (\% 3.3) işletme belirlenmiştir. İşletme sayısının belirlenmesinde örnek hacminin Yamane (2006) en az \% 3'ü ve Cochran (1977)'in belirttiği örnek hacminin \% 10'unun alınmasının yeterli olacağı ilkesi dikkate alınmıştır. Araştırmanın amacına uygun olarak hazırlanmış anket formları kullanılarak; işletmeler şansa bağlı olarak seçilerek anket çalışması yürütülmüştür. Anketlerin analizleri SPSS 21.0 paket programı kullanılarak çapraz tablolar oluşturulmuş ve önemlilik testi için ki-kare testi uygulanmıştır (Yazıcıoğlu ve Erdoğan, 2004). 


\section{Bulgular ve Tartışma}

Genel olarak frekans değerlerine göre, işletmecilerin \% 59.4'ünün hayvancilıktan memnun oldukları ve \% 88.9'unun hayvancılığı sürdürmek istedikleri belirlenmiştir. Sürdürme nedeni olarak; işletmecilerin \% 43.3'ünün başka işlerinin olmadığı, \% 20.1'inin hayvancılığı karlı bulduğu, $\%$ 18.5'inin elde ettiği gelirin kendilerine yettiği, \% 9.4'ünün hayvancılığı sevdikleri ve \% 8.7'sinin ise bu sebeplerin ikili veya üçlü kombinasyonlarından oluşan diğer nedenlerden kaynaklandığı tespit edilmiştir (Tablo 1).

İşletmecilerin sığırcılıktan memnun olma oranı diğer araştırmalarda; Şahin (1994) Ankara'da \% 54.37, Özen ve Oluğ (1996) Burdur'da \% 85.88, Ildız (1999) Tokat'ta \% 88.89, Soyak ve ark. (2007) Tekirdağ'da \% 79, Kaygisız ve ark. (2008) Kahramanmaraş'ta \% 67, Tugay ve Bakır (2009) Giresun'da \% 96 ve Koçyiğit ve ark. (2016) Erzurum Hınıs ilçesinde \% 44 olarak bildirmişlerdir. Bu araștırmada bulunan besicilikten memnuniyet oranı kimi araştırmalardan düşük kiminden yüksek ve kimine ise benzer bulunmuştur.

Soyak ve ark. (2007) Tekirdağ ilinde yaptıkları çalışmada işletmelerin \% 47'sinin hayvancılı̆̆ sürdürmek istediklerini; Koçyiğit ve ark. (2016) işletmecilerin \% 87'sinin siğırcılığg sürdürmek istedikleri ve sürdürme nedeni olarak, yapacakları başka işlerinin olmamasını (\% 37.9), elde edilen gelirin yeterli olmasını ( $\%$ 26.4), besiciliği sevdiklerini (\% 20.7) ve besiciliğin karlı olduğunu (\% 14.9) belirtmişlerdir. Bu araştırmada bulunan sürdürülebilirlik değeri Soyak ve ark. (2007)'ın bildirdiği değerden oldukça yüksek ve Koçyiğit ve ark. (2016)'nın bildirdiği değerle benzer bulunmuştur. Bu durumda işletmecilerin sığırcılığ1 önemsediklerini ve geçim kaynağı olarak gördükleri düşünülmektedir.

Benzer araştırmalarda sığır yetiştiriciliği yapma nedenlerini Giresun ilinde Tugay ve Bakır (2009) geçim kaynağı (\% 73.7), ev ihtiyacını karşılama ( $\%$ 14), geçime ilave katkı (\% 9.8), alışkanlık (\% 1.7) ve başka gelir kaynağı olmaması (\% 0.8$)$; Muş ilinde Şeker ve ark. (2012) \% 55.1'inin geçim kaynağ1 veya geçime katkı (\% 33.9) olması; Erzurum Hınıs ilçesinde Koçyiğit ve ark. (2016) \% 79'ü geçim kaynağı olarak, \% 11'i alışkanlık, $\%$ 7'si ev ihtiyaçlarını karşılamak ve \% 3'ü ise aile bütçesine katkı sağlamak olarak belirtmişlerdir. Tugay ve Bakır (2009) Giresun ilindeki işletmecilerin sığırcılıktan memnun olmayan işletmelerin \% 46.6'sı sığırcılığın karlı olmadığını, \% 20'si yemin pahalı olması ve bakımın zor olmasını ve \% 13.3'ü ise pazarının olmamasını bildirmişlerdir
Ayrıca, Ağrı ilinde yapılan araştırmada (Bakan ve Aydın, 2016), yetiştiricilerin büyük çoğunluğunun (\% 85.8) süt sı ğırcılığını ana geçim kaynağı olarak yaptıkları belirlenmiştir. Bu konuda yapılan diğer araştırmalarda (Tugay ve Bakır, 2009; Koçyiğit ve ark., 2016) ise, süt sığırcılı̆̆ının öncelikli olarak temel geçim kaynağı olarak yapıldığ 1 bildirilmektedir. Bunların aksine Tekirdağ'da yetiştiricilerin \% 57'sinin (Bintaş, 2011) ve Denizli de \% 78.8'inin hayvancılı̆̆ 1 ek gelir amaçlı yaptığı (Kayar, 2011); Erzincan'da ise \% 51.6'sının ev ihtiyacını gidermek için yaptığ (Özyürek ve ark., 2014) bildirilmektedir.

Hayvancilıktan memnuniyet ile hayvancılığ sürdürme arasındaki çapraz ilişkiye bakıldığında, hayvancılıktan memnun olan işletmecilerin tamamı hayvancılığg sürdürmek istemektedir. Hayvancılığ sürdürmek isteyen işletmecilerin \% 28.1'i başka işlerinin olmamasını ve hayvancılığın karlı olmasını ve \% 22.1'i elde edilen gelirin kendilerine yettiğ gibi, nedenlerinin olduğu tespit edilmiştir. Hayvancılıktan memnun olmayan ve aynı zamanda sürdürmek isteyen işletmecilerin $\%$ 75.2'sinin başka işleri olmadığından dolayı sürdürmek istedikleri tespit edilmiştir (Tablo 1). Belirtilen durumlardan dolayı hayvancılığı sürdürmek isteyen işletmecilerin sayılarının ve elde edilen gelirin arttırılması gerekmektedir. Bunun içinde maliyetlerin dürülmesi ve elde edilen ürünlerin değer fiyata satılması için birlik veya kooperatifçiliğin özendirilmesi önerilebilir. Bunun yanında, hayvancilıktan hem memnun olmayan hem de sürdürmek istemeyen işletmecilerin sürdürmeme nedenleri, hayvancılığın karlı olmaması (\% 72.5), zamanlarının olmaması (\% 21.5) ve hayvancılığı sevmeme (\% 5.9) olarak bulunmuştur (Tablo 1).

İşletmecilerin hayvancılıktan memnun olması ve hayvancılığı sürdürmelerine; işletmelerin bulunduğu mevki ve tipi, işletme sahibinin yaşı, eğitim durumu, hayvancılık yapılan süre ve hayvan mevcudu ve 1rk1 gibi faktörlerin etkileri incelenmiştir. Buna göre, hayvancılıktan memnun olan ve sürdürmek isteyen işletmeler ile mevkiler arasındaki ilişki istatistiki olarak önemli bulunmuştur $\quad(p<0.01)$ Varto ilçesinde işletmecilerin tamamı işi sürdürmek isterken, bu oran Malazgirt ilçesinde \% 76.8 oranı ile diğer ilçeler arasında en düşük olarak bulunmuştur. Malazgirt'te işi sürdürmek istemeyen ( $\%$ 23.2) işletmecilerin $\% \quad 81^{\prime} \mathrm{i}$ hayvancılığın karlı olmadığını, \% 14.3'ü zamanlarının olmadığını ve \% 4.8'i hayvancılığı sevmediklerini belirtmişlerdir. Korkut ve Varto ilçelerinde hayvancılığı karlı bulan işletmecilerin oranları sırasıyla \% 56.5 ve \% 32.7 iken, Hasköy'de bulunan işletmelerin tamamı karlı bulmamaktadır. Başka iş olmadığı için hayvancılığı 
sürdüren işletmelerin oranı Hasköy’de \% 72.2, Bulanık'ta \% 50.5, Varto'da \% 49.1 olarak bulunmuştur. Merkezde bulunan işletmelerin \% 85.2'si işi sürdürmek istemekte, ancak hayvancılığın karlı olmadığını ve başka işi olmadığından sürdürdüğü tespit edilmiştir. Yine burada işi sürdürmek istemeyen işletmelerin \% 66.7'si hayvancılığın karlı olmadığını belirterek, işi sürdürme nedeninde düşük karlılık oranını (\% 8.5) teyit etmektedir (Tablo 2).

İşletmecilerin \% 64'ünün hayvancilıtan memnun oldukları ve \% 72.9'unun hayvancılık dışında başka işle uğraşmadıkları tespit edilmiştir. Mevki bazında ise, en fazla memnuniyetin \% 95.8 oranıyla Korkut ilçesindeki işletmelerde olduğu, bunu \% 79.5 oraniyla Merkez'de bulunan işletmelerin izlediği belirlenmiştir. Memnun olmayan işletmelerin en fazla olduğu ilçe Hasköy olmuştur. Hasköy'de bulunan işletmelerin \% 62.5'i hayvanciliktan memnun değilken, yine bu mevkideki işletmelerin sadece \% 26.3'ünün başka işle uğraştığ 1 , aksine \% 73.7'sinin başka bir işle de uğraşmaması dikkat çekici olarak bulunmuştur (Tablo 2).

Genel olarak hayvanciliktan memnun olan işletmelerin hayvancılığı sürdürme nedenleri arasında, hayvancılıktan başka işlerinin olmaması ( $\%$ 44.8), elde edilen gelirin kendilerine yetiyor olması (\% 19.8) ve karlılık (\% 18.5) gibi faktörler ön plana çıkmaktadır. Hayvancılıktan memnun olmayan işletmecilerin ise, memnun olmamalarına rağmen hayvancılığ 1 sürdürmek istemelerinin, yoğun şekilde yapacak başka işlerinin olmamasından ileri geldiği belirlenmiştir. Hayvanc1lıktan memnuniyet ve işi sürdürme nedeni ile mevki arasındaki üçlü çapraz ilişkiye bakılmıștır. Hayvancılıktan memnuniyet ve iși sürdürme üzerine işletmelerin mevkisi çok önemli $(p<0.01)$ düzeyde etkili olmuştur. Buna göre, mevki bazında hayvancılıktan memnun olan işletmelerde karlılık faktörü Malazgirt'te \% 35.9 iken, Varto ilçesinde \% 52.9'a, Korkut ilçesinde ise \% 56.5'e yükselmiştir. Hayvancılıktan memnun olmayıp ancak işi sürdürmek isteyen işletmelerin işi sürdürme nedeni olarak yapacak başka işin olmamasının, genellikle \% 50 ve üzerinde bir orana sahip olduğu, bu oranın Merkez'deki işletmelerde \% 84.6'ya ve Hasköy'de ise \% 90.9'a yükseldiği tespit edilmiştir (Tablo 3).

Kars'ta yapılan bir araştırmada, bölgedeki yetiştiricilerin birçoğunun sığır yetiştiriciliği hakkında herhangi bir eğitiminin bulunmadığı, yetiştiricilik faaliyetlerini tamamen geleneksel yöntemlerle yaptığı ve işletme sahiplerinin çoğunun hayvancılığ 1 geçimlik olarak gördüğü ve hayvancılık sektörü dışında başka gelir kaynağının bulunmadığı bildirilmektedir (Tilki ve ark., 2013a).

Hayvancılıktan memnuniyet ve işi sürdürme üzerine işletmecilerin eğitim düzeyi çok önemli $(p<0.01)$ düzeyde etkili olmuştur. Buna göre hayvancılıktan memnun olup işi sürdürmek isteyen işletmecilerden eğitim düzeyi ortaokul ve üniversite olanlarda (\% 31.3 ve \% 33.3) karlılık faktörü öne çıkarken, okuryazar olmayanlarda ise hayvancılıktan başka işlerinin olmaması (\% 37.5) öne çıkmıştır. Ayrıca hayvancılıktan memnun olmayıp işi sürdürmek isteyen işletmecilerin eğitim düzeylerinin tamamında \% 50'nin üzerinde bir oranla yapacak başka işlerinin olmaması dikkat çekici bulunmuştur (Tablo 4).

Hayvancılıktan memnuniyet ve işi sürdürmeye işletmecilerin yaşının etkisi çok önemli bulunmuştur $(p<0.01)$. Buna göre, yaş1 30 ve altı olan işletmecilerin hayvancılıktan memnun oldukları ve \% 41.4'ünün karlı olduğunu düşündükleri için hayvancılığı sürdürmek istedikleri tespit edilmiştir. Bu oran, yaş aralığ 31 40 olan işletmecilerde \% 33.3 iken, yaş arttıkça oranın düştüğü tespit edilmiştir. Buna göre, genç ve işe yeni başlayan işletmecilerin hayvancılığ diğer yaş gruplarına göre daha çok benimsedikleri anlaşılmaktadır. Diğer faktörlerde olduğu gibi yaş faktöründe de hayvancılıktan memnun olmadığ 1 halde yapacak başka işleri olmadığı için hayvancılığı sürdüren işletmecilerin oranı bir hayli yüksek (\% 69.7-\% 87.0) bulunmuştur (Tablo 4).

İşletmelerde hayvancılıktan memnuniyet ve işi sürdürmeye işletmecilerin hayvancılık yaptıkları sürenin etkisi çok önemli $(p<0.01)$ bulunmuştur. Hayvancılıktan memnun olan ve işi sürdürmek isteyen 10 yıl ve daha az sürede hayvancılık yapan işletmecilerin işi sürdürme nedeni olarak karlılık faktörü \% 49.2 oranıyla en yüksek bulunmuştur. Ancak, bu gruptaki işletmecilerin hayvancılıktan memnun olmamasına rağmen, \% 75 oranında yapacak başka işleri olmadı̆̆ sürdürdükleri tespit edilmiştir. Karlılık faktörüne ait bu oran hayvancılık yaptığı süre 21-30 arasında olan işletmelerde \% 6'ya düşmüştür. $\mathrm{Bu}$ işletmelerde iși sürdürme nedeni olarak \% 32 oranında yetiyor ve \% 40 oranında yapacak başka işlerinin olmaması gibi faktörler öne çıkmıştır. Yaş ile hayvancılık yapılan süre arasında yapılan çapraz analizde, $30 \leq$ yaşa sahip işletmecilerin \% $74.5^{\prime}$ 'inin hayvancılık yaptıkları sürenin $10 \leq$ yıl olan işletmeciler olduğu belirlenmiştir. Buna göre, genç işletmecilerin hayvancılı̆̆ geçim kaynağı olarak gördükleri anlaşılmaktadır. Ayrıca, 21-30 yıl hayvancılık yapan işletmecilerin, hayvancılıktan memnun olmalarına rağmen, başka iș olmadı ̆̆ için yapanların oranı diğerlerine göre daha yüksek (\% 40) bulunmuştur. Yine bu yaş grubunda, 


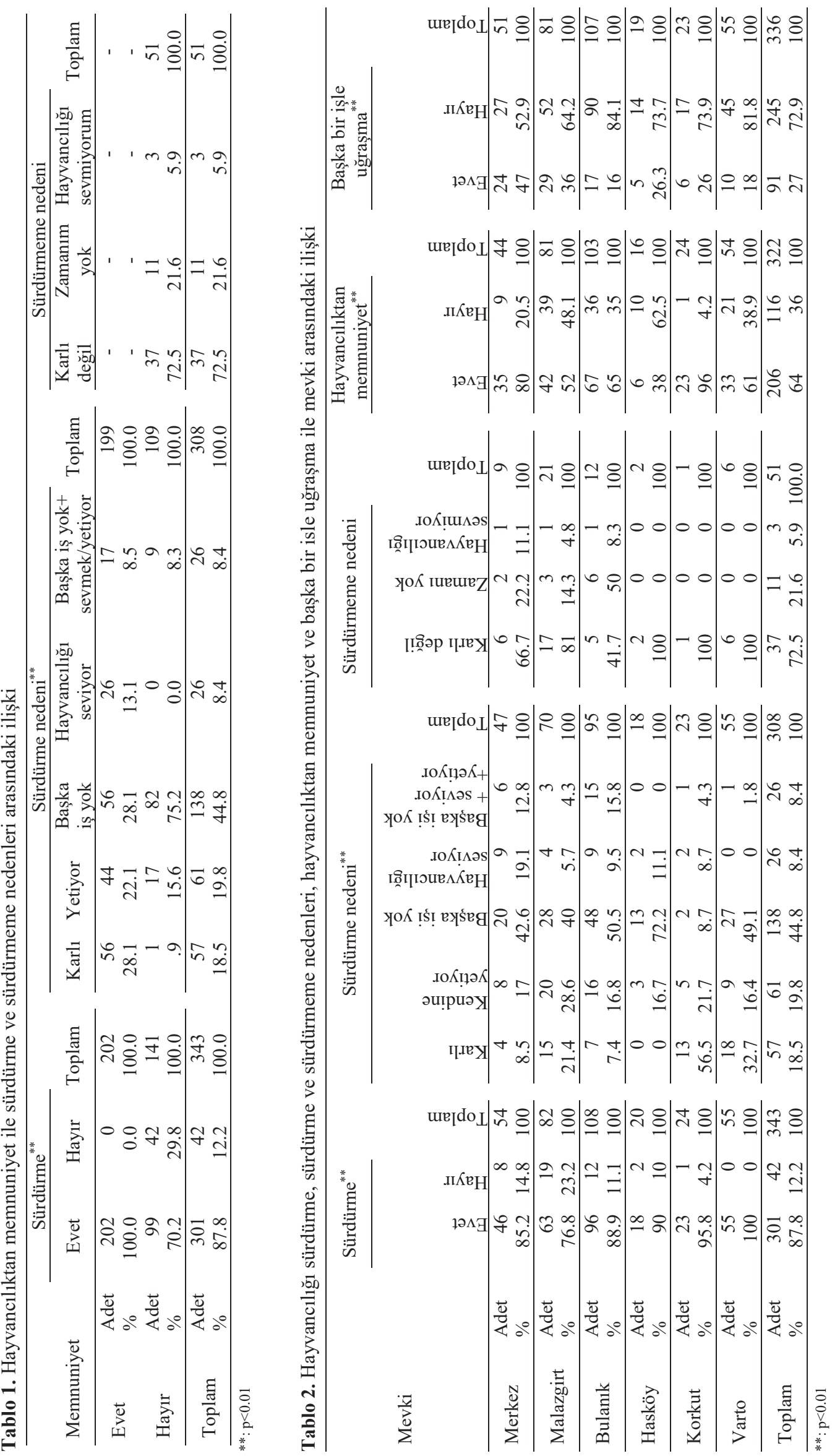




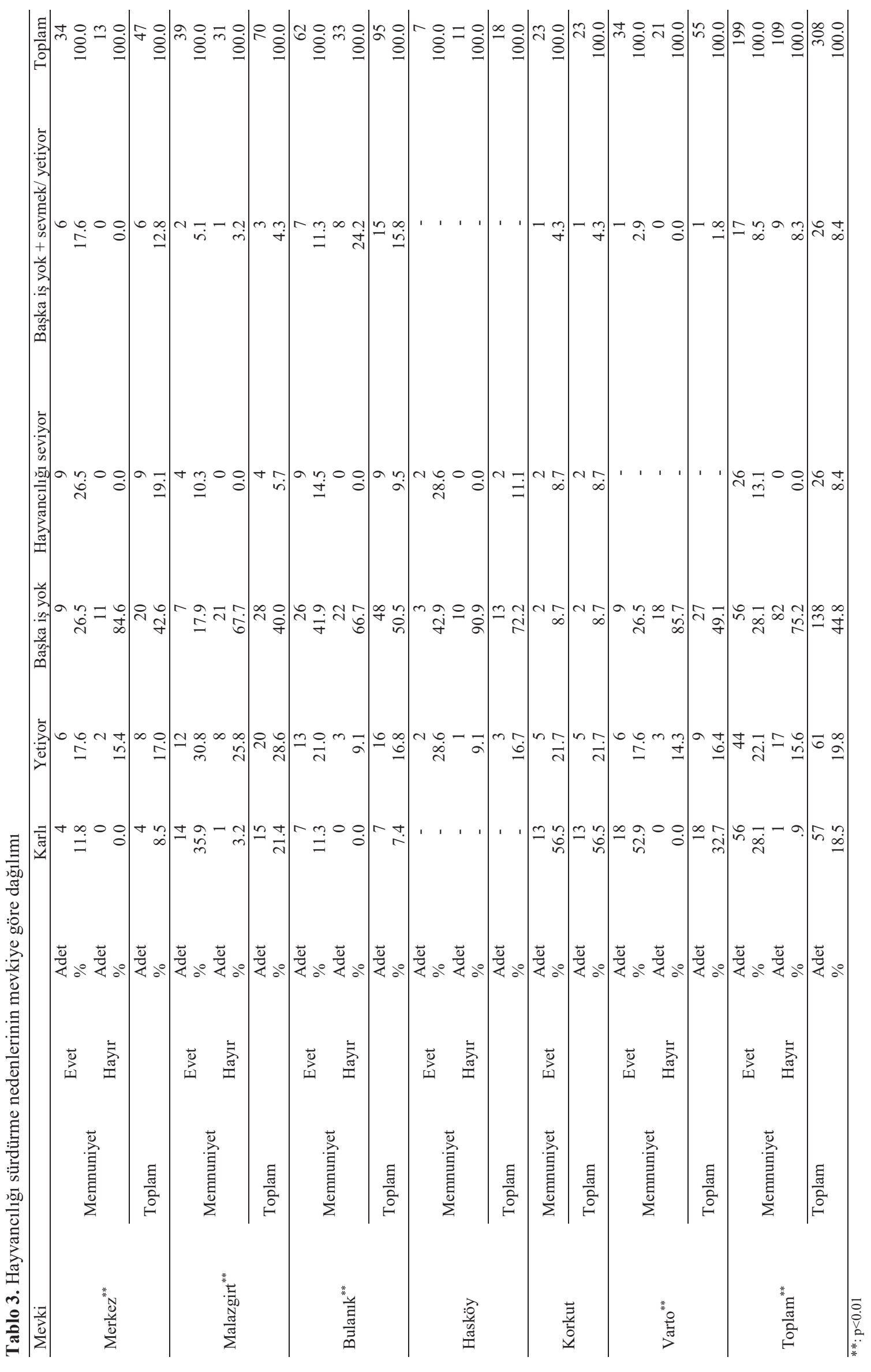




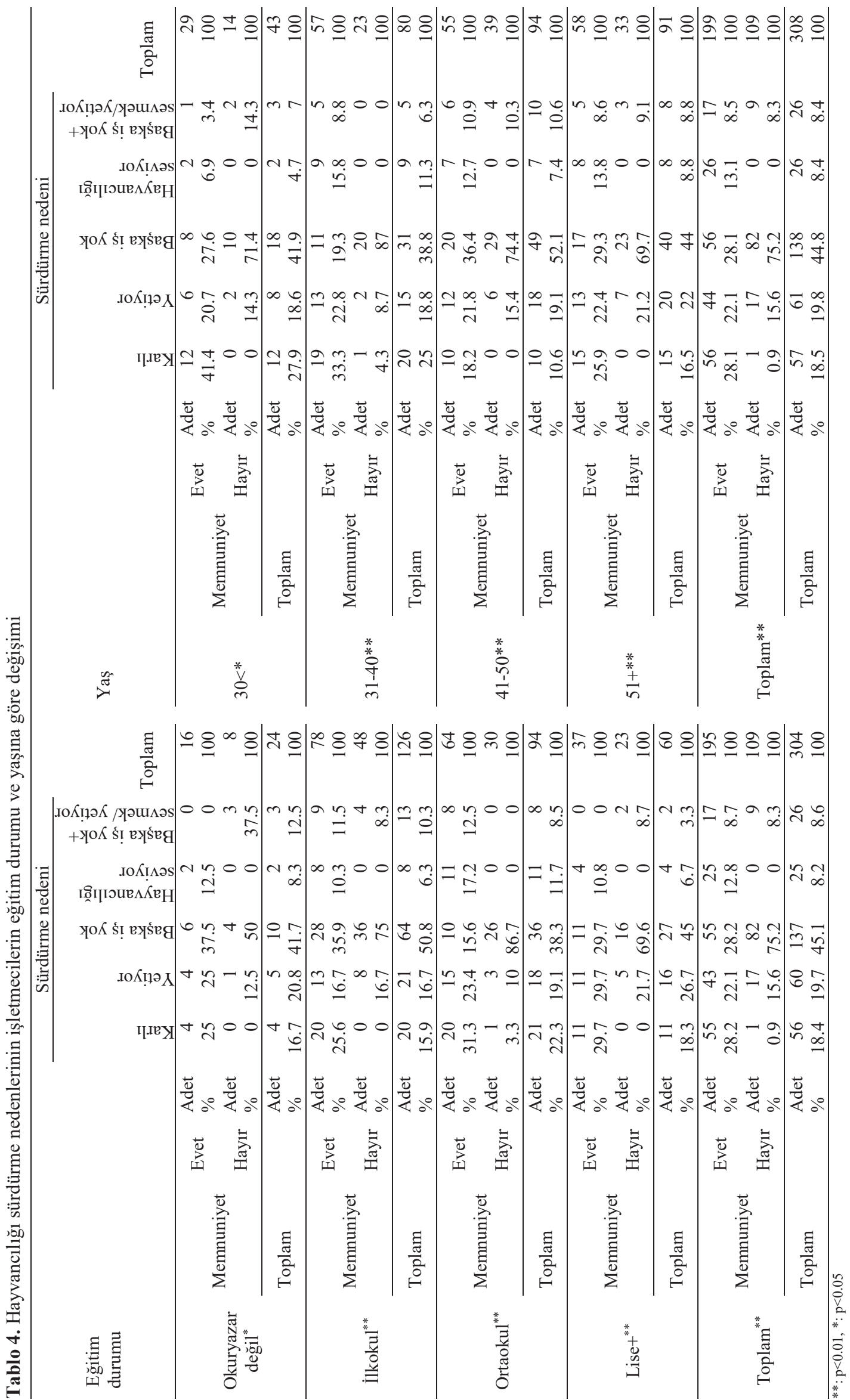


hayvancılığı sevdikleri için yapan işletmelerin oranı diğerlerine göre daha yüksek (\% 16) olması dikkat çekici bulunmuştur. Hayvancılıktan memnun olmayan ancak işi sürdürmek isteyen işletmelerde faktör olarak, yapacak başka işin olmamasına ait oran 31 yıl ve üzeri hayvancılık yapan işletmelerde en düşük (\% 34.6) iken, bu oran 11-20 y1l arasında hayvancilı yapan işletmelerde \% 82.1'e yükselmiştir (Tablo 5).

Ağrı ilinde yapılan araştırmada Bakan ve Aydın (2016) işletmecilerin hayvancılık ile uğraşma sürelerini ortalama $24.3 \pm 1.2$ y1l, Özyürek ve ark. (2014) ve Şahin ve Gürsoy (2016) sirasıyla Erzincan'da 22.2 yıl ve Iğdır'da 25.74 yıl, Erdoğan ve ark. (2004) Kars'ta 31.1 yil ve Tilki ve ark. (2013b) Kars ilinde 30.2 y1l olarak bildirilmektedir. Ayrıca, 11-20 yıl aralığında deneyime sahip yetiştiricilerin oranı Rize ilinde \% 71.1 (Savaş ve Yenice, 2016), Erzurum ili Hınıs ilçesinde \% 45.87 (Güler ve ark., 2016) olarak bulunmuştur.

İşletmelerde hayvancılıktan memnuniyet ve işi sürdürmeye işletmelerde bulunan hayvan sayısının etkisi çok önemli bulunmuştur $(p<0.01)$. Buna göre hayvanciliktan memnun olan ve işi sürdürmek isteyen ve hayvan sayısı 9'un altında olan işletmelerde neden olarak, karlılık \% 32.6 oranıyla ilk sırada yer almıştır. Karlılığa ait bu oran hayvan sayıs1 21-40 olan işletmelerde \% 34.8 'e yükselmiştir. Ancak, bu grupta hayvancılıktan memnun olmayıp, başka iş olmadığı için işi sürdürmek isteyenlerin oranı diğer gruplara göre en yüksek (\% 82.4) olması dikkat çekici bulunmuştur (Tablo 5).

Bakan ve Aydın (2016) tarafından Ağrı ilinde yapılan araştırmada, işletmelerde bulunan sığır sayısını ortalama $19.9 \pm 2.5$ baş olarak, gruplama sıralamasında ise işletmelerin \% 32'si 11-15 baş, $\%$ 25.5'i ise 21 baş ve üzeri, \% 20.8'i 6-10 baş \% 17.9'u 16-20 baş sı̆̆ıra sahip olduklarını bildirmektedirler. $\mathrm{Bu}$ konuda yapılan diğer çalışmalarda işletme başına düşen sığır sayısı; Kars'ta 23.4 baş (Erdoğan ve ark., 2004), Erzurum'da 18 baş (Çoban ve ark., 2013) ve Sivas ilinde 23.8 baș (Akkuş, 2009; Hozman ve Akçay, 2016) olarak belirlenmiştir. İşletme başına düşen sığır sayısının en düşük olduğu ilin ise 1.9 baş ile Rize (Savaş ve Yenice, 2016) olduğu tespit edilmiştir.

Hayvancılıktan memnuniyet ve işi sürdürmeye işletme tipinin etkisi çok önemli bulunmuştur $(p<0.01)$. Buna göre, süt işletmelerinde hayvancılıktan memnuniyet ve işi sürdürmede öne çıkan faktör \% 36.4 oranıyla karlılık olmuştur. Kombine verimli işletmelerde ise öne çıkan faktör \% 32 oranıyla hayvancılıktan başka işin olmadığı tespit edilmiştir. Hayvancılıktan memnun olmayıp ancak hayvancılığı da sürdürmek isteyen süt ve kombine tipindeki işletmelerin neden olarak yapacak başka işlerinin olmadığ $\%$ 74.1) tespit edilmiştir (Tablo 6).

Hayvancılıktan memnuniyet ve işi sürdürmeye ırkın çok önemli $(p<0.01)$ bir faktör olduğu ve işletmelerde yetiştirilen 1rka göre işi sürdürme nedenlerinde değişiklik görülmüştür. Buna göre, hayvancilıktan memnun olup yerli 1rk olan işletmelerin işi sürdürme nedeni olarak başka işlerinin olmaması (\% 37.5) ön plana çıkmıştır. Bu işletmelerde, elde edilen gelirin yetiyor seçeneği $\% 25$ oranıyla ikinci sırada gelirken, karlılık faktörü \% 12.5 oranıyla en düşük düzeyde kalmıştır. Yine bu işletmelerde hayvancılıktan memnun olmayıp, ancak işi sürdürmek isteyenlerin elde edilen gelirin yetiyor olması \% 30.8 oranında bulunmuştur. Bu işletmelerde hayvancılıkta karlılık sürdürülebilirlik için olmaz şart olarak görülmemektedir. Buna karşın, hayvancılıktan memnun olan ve işi sürdürmek isteyen ve işletmesinde kültür 1 rk1 bulunan işletmelerde ise karlılık (\%51.6) ön plana çıkmıştır. Diğer taraftan hayvancılıktan memnun olmayan ve işi sürdürmek isteyen işletmelerde hayvancılıktan başka yapacak işin olmaması sirasiyla \% 69.2, \% 71.1, \% 75.0, \% 75.9 ve \% 84.6 oranlarında bulunmuştur (Tablo 7). İşletmesinde yerli, kültür veya melez 1 rk bulunduran yetiştiricilerin süt sığırcılığından memnun olmadikları halde devam etmelerinin nedeni yapacak başka işlerinin olmamasından kaynaklanmaktadır. Ancak memnun olanlar ise sürdürme nedeni olarak, yerli 1rkı olan yetiştiriciler yine başka işlerinin olmamasını, kültür ve melez 1rk1 olanlar ise karlı olmasından dolayı sürdürdüklerini bildirmişlerdir. Yani işletmelerinde kültür ve melez ırkı bulunan işletmecilerin daha iyi kazanç elde ettiği düşünülmektedir.

Hayvancılıktan memnun olup ancak başka işle uğraşan işletmelerin işi sürdürme nedeni olarak karlılık (\% 30.9) ön plana çıkarken, bunu \% 27.3 oranıla elde edilen gelirin yetiyor olması izlemektedir. Hayvancılıktan başka işle uğraşan ve hayvancilıktan memnun olmayan işletmelerde işi sürdürme nedeni olarak \% 72 oranında yapacak başka işin olmaması bulunmuştur. Diğer taraftan hayvancılıktan başka işle uğraşmayan ve hayvancilıktan memnun olan ve olmayan işletmelerde hayvancılığı sürdürme nedeni olarak yapacak başka işin olmaması \% 33.1 ve $\% 76.2$ bulunmuştur. Hayvancılıktan başka işle uğraşmayan ve hayvancilıktan memnun olan ve olmayan işletmelerin işi sürdürme nedeni olarak, \% 61.1 oranıyla hayvancılığın karlı olmadığ düşüncesinin yaygın olduğu tespit edilmiştir (Tablo $6)$. 


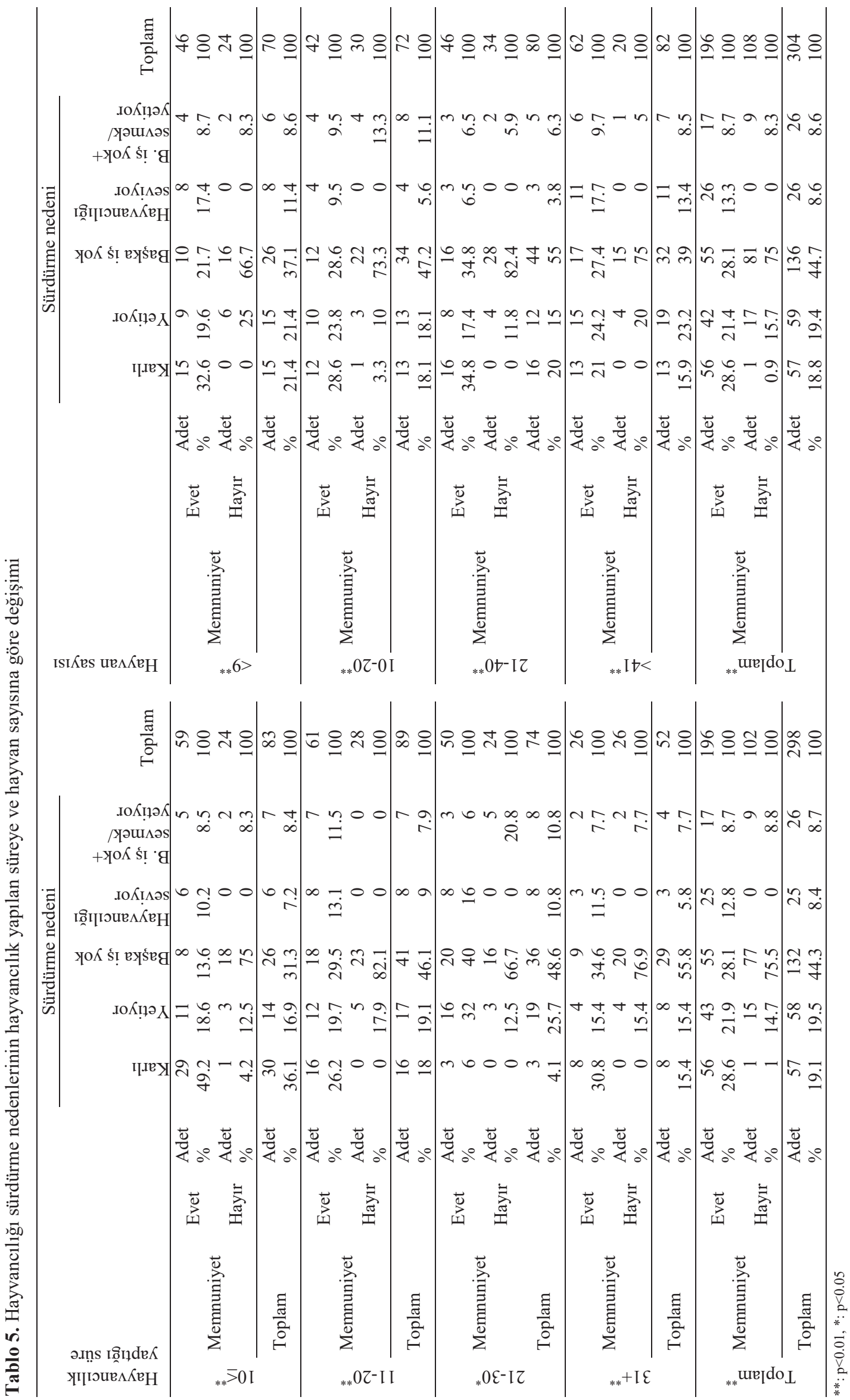




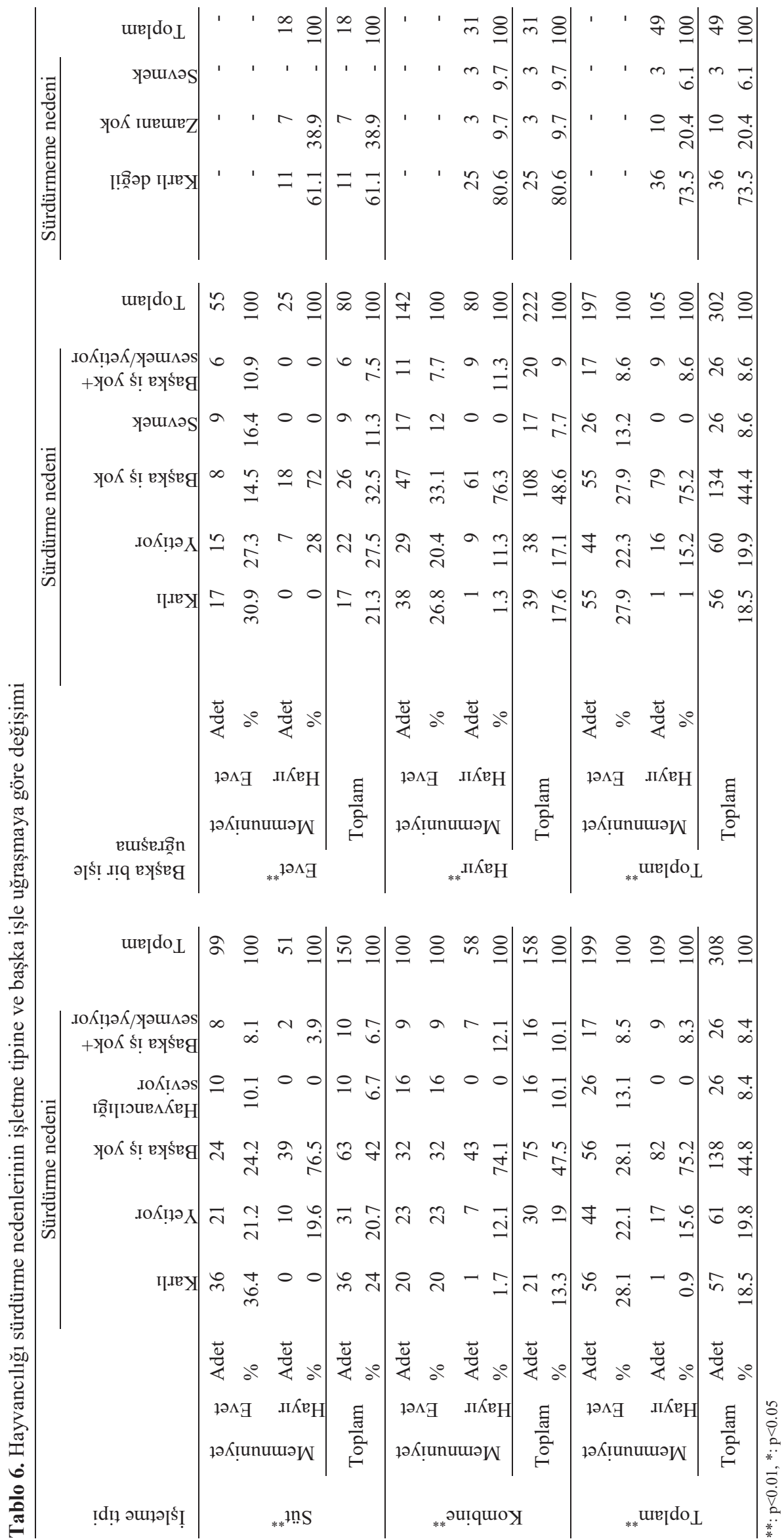




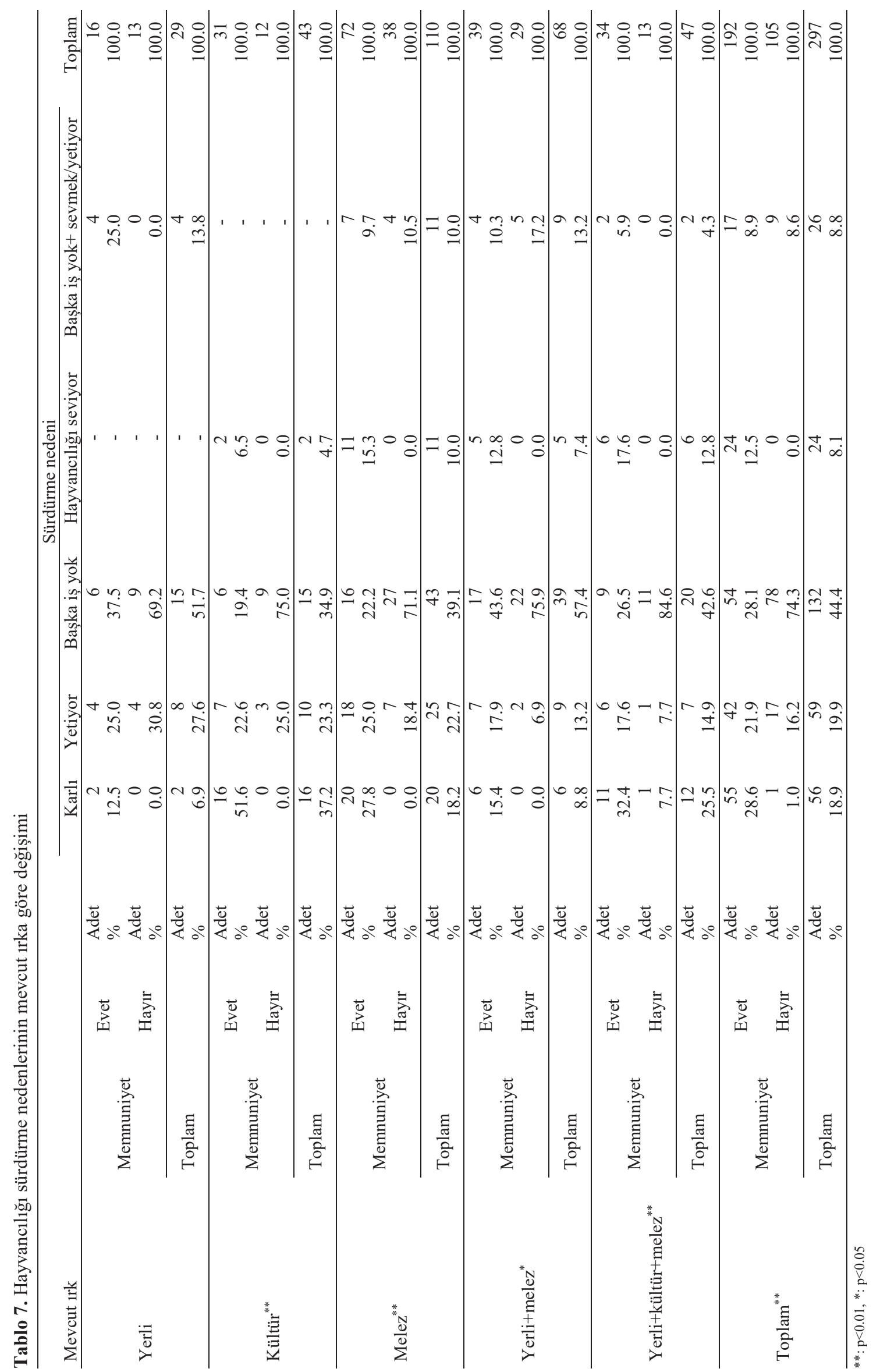


Bu konuda yapılan diğer araştırmalarda, Ağrı ilindeki yetiştiricilerin ana faaliyetinin tarım ve hayvancılık olduğu, işletmecilerin \% 96.2'sinin süt sığırcılığ1 dışında da faaliyet gösterdiği; bu faaliyetlerin \% 83.1'ini yine tarımın diğer kolları, çok az bir kısmı ticaret (\% 8.8'i) ve memurluk (\% 4.8'i) yaptığ bildirilmektedir (Bakan ve Aydın, 2016). Ayrıca, işletmecilerin süt sığırcılığ1 dışındaki faaliyetlere ait oranı Şeker ve ark. (2012) Muş ilinde \% 52.0; Özyürek ve ark. (2014) Erzincan'da \% 62.6; Hozman ve Akçay (2016) Sivas'ta \% 63.0; Savaş ve Yenice (2016) Rize'de \% 91.9; Koçyiğit ve ark. (2016) Hınıs ilçesinde $\%$ 17.0, başka bir faaliyetle uğraşmayanların oranını \% 83.0 olarak bildirmişlerdir.

\section{Sonuçlar}

Sonuç olarak, Muş ilindeki büyükbaş süt sığırı işletmelerinde yetiştiricilerin süt sığırcılığından memnun oldukları ve sürdürmek istedikleri belirlenmiştir. Muş ilinde süt sığırcılığının sürdürülebilir olması ve sürdürmek isteyen işletmecilerin sayılarının artırılması için, yetiştiricilerin elde ettiği gelirin artırılması ve işletme maliyetinin düșürülmesi gerekmektedir. Bunun içinde devletin teşvik sisteminin artırılarak devam etmesi ve elde edilen ürünlerin değer fiyata satılması için aracılar yerine ürünün direkt tüketiciye ulaşmasını sağlayan birlik veya kooperatifçiliğin özendirilmesi önerilebilir.

\section{Kaynaklar}

Akkuş, Z., 2009. Konya ilindeki süt sığırcılığı işletmelerinin yapısal özellikleri. Yüksek lisans tezi, Selçuk Üniversitesi Fen Bilimleri Enstitüsü, Konya.

Anonim, 2019. Hayvancilik İstatistikleri. (http://tuik.gov.tr/PreTablo.do?alt id=1002), (Erișim tarihi: 18.03.2019).

Bakan, Ö., Aydın, R., 2016. Ağrı ili süt sığırcılığı işletmelerinin sosyo-ekonomik özellikleri. Journal of the Faculty of Agriculture, 47(2): 113-122.

Bakır, G., 2002. Van ilindeki özel süt sığırcılığı isletmelerinin yapısal durumu. Yüzüncü $Y l l$ Üniversitesi Tarım Bilimleri Dergisi, 12(2): 1-10.

Bintaş, H., 2011. Trakya bölgesindeki süt sığırcılığı işletmelerinin yapısal ve ekonomik sorunları üzerine bir araștırma. Yüksek lisans tezi, Namık Kemal Üniversitesi Fen Bilimleri Enstitüsü, Tekirdağ.

Cochran, W.G.,1977. Sampling Techniques (3rd Edition). John Wiley\&Sons, New York.

Çoban, O., Laçin, E., Sabuncuoğlu, N., Genç, M., 2013. Production and health parameters in cattle herds: A Survey from Eastern Turkey. The Journal of Animal and Plant Sciences, 23(6): 1572-1577.

Erdoğan, H.M., Çitil, M., Güneş, V., Saatci, M., 2004. Dairy cattle farming in Kars district, Turkey: I. Characteristics and production. Turkish Journal of
Veterinary and Anima ISciences, 28(4): 735-743.

Güler, O., Aydın, R., Yanar, M., Diler, A., Koçyiğit, R., Avcı, M., 2016. Erzurum ili Hınıs ilçesi sığırcılık işletmelerinin sosyo-ekonomik yapısı. Alınteri Zirai Bilimler Dergisi, 30(1): 27-37.

Hozman, S.B., Akçay, H., 2016. Sivas ili damızlık sığır yetiştiricileri birliğine üye süt sığırcılığ işletmelerinin bazı teknik ve ekonomik özellikleri. Tarım Ekonomisi Dergisi, 22(1): 57-65.

Ildız, F., 1999. Tokat İli merkez ilçesinde ithal sığır yetiștiren tarım işletmelerinin yapısı. Yüksek lisans tezi, Ankara Üniversitesi Fen Bilimleri Enstitüsü, Ankara.

Kayar, Y., 2011. Denizli yöresi süt sığırcılığı işletmelerinde barınakların yapısal yönden değerlendirilmesi. Yüksek lisans tezi, Adnan Menderes Üniversitesi Fen Bilimleri Enstitüsü, Aydın.

Kaygısız, A., Tümer, R., Orhan, H., Vanlı, Y., 2008. Kahramanmaraş Bölgesi Süt Sığırı İșletmelerinin Yapısal Özellikleri: I. Yetiştirme Uygulamaları. Süleyman Demirel Üniv. Ziraat Fakültesi Dergisi, 3(2): 23-31.

Kibar, M., Bakır, G., 2018. Siirt ili koşullarında yetiștirilen siyah alaca sığırlarda 1s1 stresinin süt verim ve kompozisyonu üzerine etkisi. Yüksek lisans tezi, Siirt Üniversitesi Fen Bilimleri Enstitüsü, Siirt.

Koçyiğit, R., Diler, A., Yanar, M., Güler, O., Aydın, R., Avc1, M., 2016. Süt sığırcılığı işletmelerinde hayvan sağlığı, veteriner sağlık hizmetleri ve yetiştirici memnuniyeti: Erzurum ili Hınıs ilçesi örneği. Türk Tarım ve Doğa Bilimleri Dergisi, 3(1): 24-32.

Özen, N., Oluğ, H.H., 1996. Burdur süt sığırcılığının sorunları ve çözüm önerileri. Akdeniz Üniversitesi Ziraat Fakültesi Dergisi, 9(1): 309-321.

Özyürek, S., Koçyiğit, R., Tüzemen, N., 2014. Erzincan ilinde süt sığırcıllı̆̆ yapan işletmelerin yapısal özellikleri: Çayırlı ilçesi örneği. Tekirdă̆ Ziraat Fakültesi Dergisi, 11(3): 19-26.

Pezikoğlu, F., 2012. Sürdürülebilir tarım ve kırsal kalkınma kavramı içinde tarım-turizm-kırsal alan ilișkisi ve sonuçları. Karamanoğlu Mehmetbey Üniversitesi Sosyal ve Ekonomik Araştırmalar Dergisi, 14(22): 83-92.

Savaş, S., Yenice, G., 2016. Rize ilinde yapılan süt sığırcılığının mevcut durumunun araştırılması. Atatürk Üniversitesi Veteriner Bilimleri Dergisi, 11(1): 74-83.

Soyak, A, Soysal, Mİ., Gürcan, EK., 2007. Tekirdağ ilindeki süt sığırcılığ 1 işletmelerinin yapısal özellikleri ve bu işletmelerdeki siyah alaca süt sığırlarının çeşitli morfolojik özellikleri üzerine bir araştırma. Tekirdăg Ziraat Fakültesi Dergisi, 4(3): 297-305.

Şahin, K., Gürsoy, A.K., 2016. Iğdır ili süt sığırcıllı̆̆ işletmelerinin sosyo-ekonomik yapısı. Nevşehir Bilim ve Teknoloji Dergisi, TARGID Özel Sayı: 118-129.

Şahin, O. 1994. Ayaş ilçesine bağlı köylerdeki süt sığırcılığının yapısı. Yüksek lisans tezi, Ankara Üniversitesi Fen Bilimleri Enstitüsü, Ankara. 
Şeker, İ., Tasalı, H., Güler, H., 2012. Muş ilinde sı̆̆ır yetiştiriciliği yapılan işletmelerin yapısal özellikleri. Fırat Üniversitesi Să̆llk Bilimleri Veteriner Dergisi, 26(1): 9-16.

Tilki, M., Aydın, E., Sarı, M., Aksoy, A.R., Önk, K., 2013a. Kars ili sığır işletmelerinde barınakların mevcut durumu ve yetiștirici talepleri: II. Yetiștirici talepleri. Kafkas Universitesi Veteriner Fakültesi Dergisi, 19(2): 191-197.

Tilki, M., Sarı, M., Aydın, E., Işık, S., Aksoy, A.R., 2013b. Kars ili sı̆̆ır işletmelerinde barınakların mevcut durumu ve yetiștirici talepleri: I. Mevcut durum. Kafkas Üniversitesi Veteriner Fakültesi
Dergisi, 19(1): 109-116.

Tugay, A., Bakır, G., 2009. Giresun yöresindeki süt sığırcılığ 1 ișletmelerinin yapısal özellikleri. Atatürk Üniversitesi Ziraat Fakültesi Dergisi, 40(1): 37-47.

Turhan, Ş., 2005. Tarımda sürdürülebilirlik ve organik tarım. Tarım Ekonomisi Dergisi, 11(1): 13-24.

Yamane, T., 2006. Temel Örnekleme Yöntemleri. Çeviri: Esin, A., Bakır, M.A., Aydın, C, Güzbüzsel, E., Literatür Yayınları: 53, İstanbul.

Yazıcıoğlu, Y., Erdoğan, S., 2004. SPSS Uygulamalı Bilimsel Araştırma Yöntemleri. Detay Yayıncılık, Ankara, s. 49-50. 